\title{
INTEGRATED GEOTECHNICAL AND HYDROGEOPHYSICAL INVESTIGATION OF THE EPE WETLAND DUMPSITE IN LAGOS STATE, NIGERIA
}

\author{
${ }^{1}$ Orakwe L. O.; ${ }^{2}$ Olorunfemi M. O.; ${ }^{3}$ Ofoezie I. E. and ${ }^{2}$ Oni A. G. \\ Lagos Waste Management Authority, 3 Otto Road Ijora, Lagos State Nigeria \\ ${ }^{2}$ Geology Department, Obafemi Awolowo University, Ile-Ife, Nigeria \\ ${ }^{3}$ Institute of Ecology and Environmental Studies, Obafemi Awolowo University, Ile-Ife, Nigeria \\ Corresponding Author: orakwelinus@yahoo.com \\ (Received: 30th June, 2018 Accepted: 29 $9^{\text {th }}$ Oct., 2018)
}

\section{ABSTRACT}

\begin{abstract}
Integrated geotechnical and geophysical investigation of a wetland dumpsite in Epe, Lagos State, Nigeria, was carried out with a view to determining the hydraulic properties of the underlying formation for possible leachate transmission and subsequent subsoil pollution. Eleven boreholes were drilled, lithologically logged, sampled and analysed for hydraulic/hydrogeological parameters. Geophysical investigation involved 1-D Vertical Electrical Soundings (VES) (8 Nos.) and 2-D Dipole-Dipole profiling along five traverses. The survey area is underlain by fine-medium grained sands with coefficient of uniformity values of $<6$. The fresh water saturated sandy formation is characterized by relatively high layer resistivity values $(5681-9889 \Omega \mathrm{m})$. The mean bulkdensity is $1.89 \pm 0.162 \mathrm{~g} / \mathrm{cm}^{3}$; porosity: $37.84 \pm 8.42 \%$; and permeability: $3.0 \times 10^{-4} \pm 1.1 \times 10^{-4} \mathrm{~cm} / \mathrm{sec}$. The $2 \mathrm{D}$ images identify leachate impacted zone beneath the waste dump site and its periphery characterized by relatively low resistivity values (4 to $165 \Omega \mathrm{m}$ ). The study concluded that the sandy nature of the subsoil and its moderate permeability aided subsoil and groundwater pollution by leachate to depths in excess of $15 \mathrm{~m}$.
\end{abstract}

Keywords: Boreholes, Dumpsite, Hydraulic Property, Pollution Plume, Soil and Wetland

\section{INTRODUCTION}

Over the years, inadequate and less considerations of the geological settings of an environment before the location and design of landfills have contributed to negative impacts witnessed in such ecosystem as a result of leachate migration and eventual contamination of neighbouring water resources (Splajt et al., 2003; Oyediran and Adeyemi, 2011). While site-specific investigations are necessary to delineate the underlying geology and establish suitability of areas marked out for the construction of landfills, standard organizations have emphasized global restrictions on the construction of landfills in areas with peculiar geologic conditions like faults, wetlands and flood plains (Hughes, 1972; USEPA, 2012; USEPA, 2014; Derakhshandeh and Toktam, 2014). According to Lee et al. (1999), it is only a matter of time before the groundwater resource around landfills underlain by geologically unstable condition becomes contaminated by leachates emanating from washed or decomposing waste materials. Beyond site selection, outcomes of both geological and geophysical site-surveys also constitute parts of local parameters considered during the design stage of landfills (Hughes, 1972; Parametrix, 1987).These knowledge help in the determination and inclusion of necessary control measure with a view to preventing future failures and subsequent contamination of receiving water resources (Walker and Anderson, 2001). According to O'Leary (1983), data required for proper understanding of geological/geotechnical conditions of areas proposed for landfill design include depth to, type/or nature of and the sequence of the subsoils; physical characteristics of the subsoils which include grain size and permeability; location of outcrops; regional geology; hydrogeological setting and groundwater quality. In the past, physical characteristics of soil profile, depth and thickness of subsurface geologic layers, have been successfully delineated using both geophysical method and well log analysis (Ross et al., 1990; Enikanselu, 2008 and Ibitola et al., 2011). These methods aid better understanding of the rock sequence underlying the source of leachate and therefore give an idea on the vulnerability of the water bearing layer (aquifer) to contamination, a situation which can be established through hydro-chemical studies of receiving water bodies (Longe and Balogun, 2010; Nitin and Mohrana, 2013). Geophysical methods have also been successfully used to map pollution plume that contaminates soils and water resources around dumpsites (Enikanselu, 2008; Ibitola et al., 2011). Dumpsites, being the commonest waste 
management method used in most states in Nigeria, are often located on different geologic settings. The vulnerability of their underlying aquifer depends on the geology.

Until recent when a dumpsite was established on low lying wetland, refuse dumping in Lagos State had been upland. The paradigm shift has been a source of concern, because the policy violated classical criteria in landfill location. According to USEPA's code of Federal regulations, landfills should not be built near locations that are not geologically suitable, including faults, flood plains, wetlands, or any other restricted area (USEPA, 2014). This study therefore intends to investigate the impact of the Epe wetland dumpsite on the soil/subsoil and water resources around the waste dumpsite using integrated approach.

\section{THE STUDY AREA}

The Epe wetland dumpsite is located in Epe Local Government Area of Lagos State which lies between Latitudes $6^{\circ} 33^{\prime} 00^{\prime \prime}$ and $6^{\circ} 35^{\prime} 00^{\prime \prime} \mathrm{N}$ and Longitudes $3^{\circ} 55^{\prime} 30^{\prime \prime}$ and $3^{\circ} 56^{\prime} 30^{\prime \prime} \mathrm{E}$ on the northern flank of the Coastal Lagos Lagoon. It is underlain by the Coastal Plain Sands (CPS) of the Dahomey Basin (Fig.1). The geologic succession underlying the study area spans through the Cretaceous Abeokuta Formation, which unconformably overlies the rocks of the Precambrian Basement Complex to the Quaternary Coastal Alluvium (Obiora and Onwuka, 2005). Explaining further the depositional process, Opara (2011) noted that a continuation of the marine transgression during the Paleocene led to the deposition of shallow marine limestones of the Ewekoro Formation and the shales of the Akinbo Formation. On top of the Paleocene sequence is the Eocene shales of the Oshosun Formation and the sandstones of the Ilaro Formation. Chronologically, lithostratigraphic units of the Dahomey Basin were recognized to include those of the Abeokuta Group consisting Ise, Afowo and Araromi Formations; the Imo Group consisting Ewekoro and Akinbo Formations; others include Ilaro Formation and the Coastal Plain Sands (Jones and Hockey, 1964; Omatsola and Adegoke, 1981; Akinmosin et al., 2010) (Fig. 2)

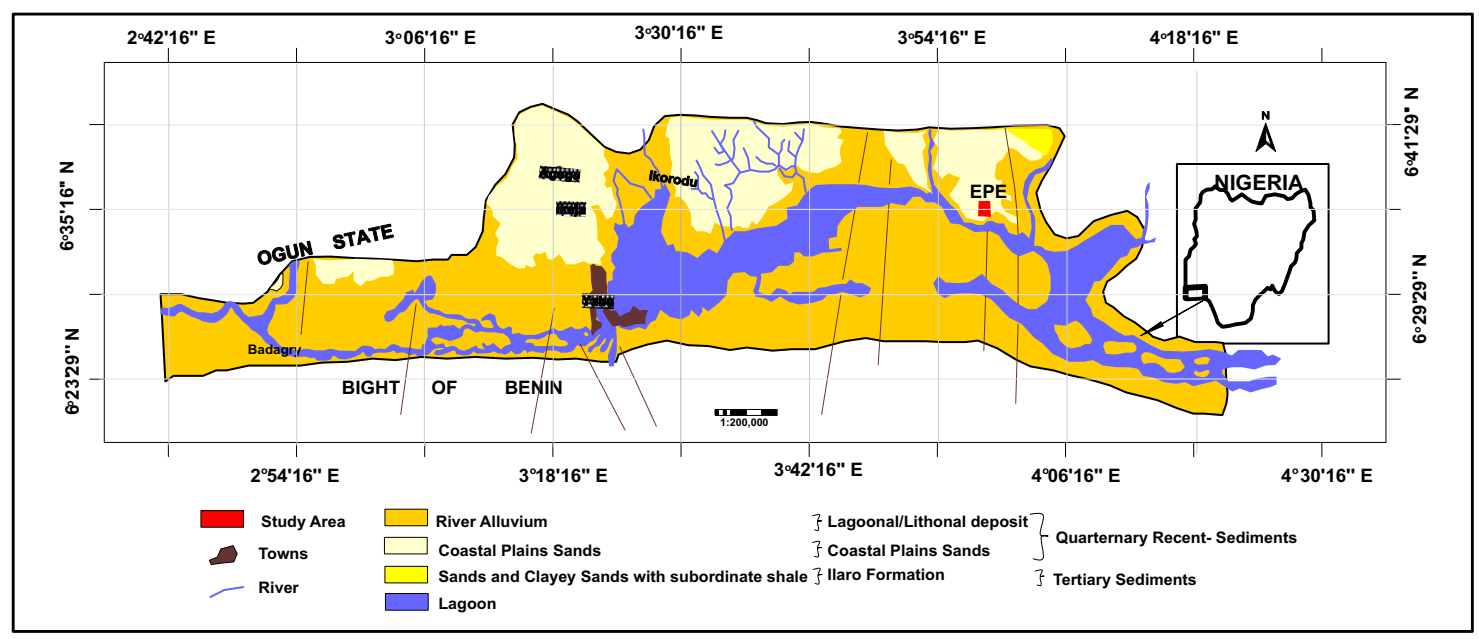

Fig 1: Geological Map of Lagos State, Nigeria, Showing the Study Area (Nigeria Geological Survey Agency, 2006). 


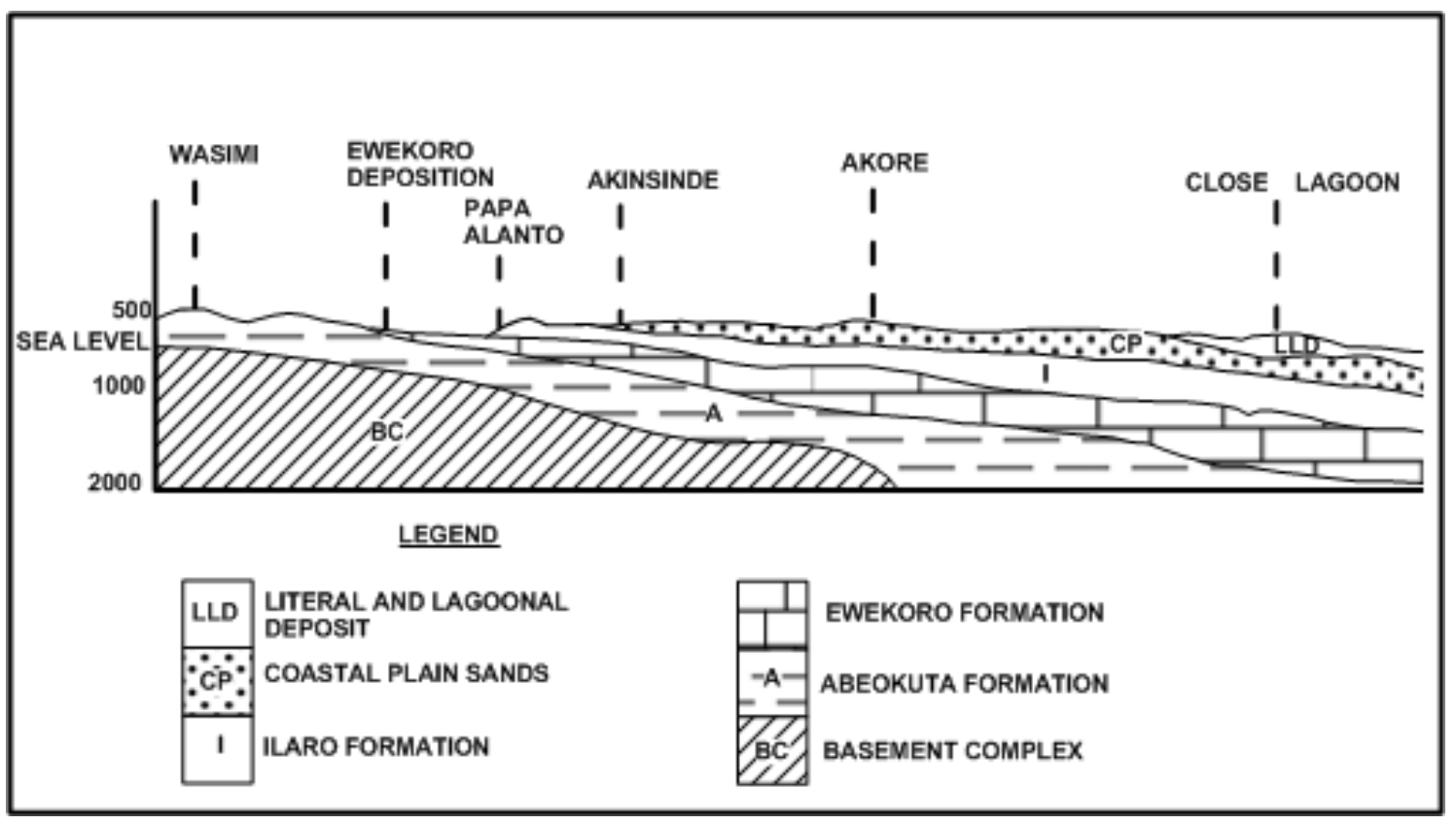

Fig. 2: Generalized Stratigraphic Cross Section (N-S) across the Dahomey Basin (Onyegoke, 1986)

\section{Coastal Plains Sands (CPS)}

The Coastal Plain Sands (Benin Formation) ranges in age from Oligocene to Pleistocene. It is the youngest formation in the basin and overlies the Ilaro Formation. The formation consists of very poorly sorted clayey/pebbly sands, sandy clay and rare thin lignite (Akinmosin et al., 2010). The clay components occur as lenses while thick bodies of yellowish and white sands are occasionally cross bedded (Longe, 2011; Adeigbe et al., 2014). Though the layers are somewhat lenticular, some are of rather limited lateral extension (Longe, 2011).It lacks fossils but contains plant remains which have been used to date the formation. The CPS is overlain by a younger unit known as the Recent Alluvium that outcrops at the road cuttings between Ofada and Mokoloki on the Ogun River as coarse clayey sorted sands with clay lenses and occasional pebble (Akinmosin et al.,2010). Though identified to be underlain majorly by the Coastal Plain Sands (CPS), a deeper understanding of local geological condition of the Epe dumpsite is necessary to ascertain if this could provide natural attenuation condition to protect groundwater from being contaminated by leachate emanating from overlying solid waste in dumpsite.

\section{MATERIALS AND METHODS OF STUDY}

This study adopted geophysical and geotechnical methods to delineate subsurface geologic formations, map pollution of the subsoil and determine the hydraulic/hydro-geological characteristics of the underlying soil profile. The electrical resistivity method involving both 1-D Vertical Electrical Sounding (VES) and 2-D Dipole-Dipole profiling techniques were adopted for the geophysical investigation. Five (5) traverses (TR1 - TR5) that ran in the N-S, W-E and NE-SW directions(Fig. 3) were established along which 2$\mathrm{D}$ imaging was carried out. The 2-D imaging data acquisition involved the use of Dipole-Dipole array with dipole length (a) ranging between 5 and $10 \mathrm{~m}$ and expansion factor, $\mathrm{n}$, varying from 1-5. The 2-D Dipole-Dipole data were inverted into 2D resistivity structures using the DIPRO for window software. Eight (8) VES stations, with two VES along each traverse line were conducted using the Schlumberger array. The depth sounding curves were interpreted quantitatively using the partial curve matching technique and computer assisted 1-D forward modeling with the WinRESIST version 1.0 software. Eleven boreholes (4 new and 7 existing boreholes) (Fig. 4) were drilled within the study area. The logs data from these holes were used to developed the lithologic unit beneath the study area while eighteen (18) profile soil samples (SS1 to SS18) collected from the four new boreholes (BH1, $\mathrm{BH} 2, \mathrm{BH} 3$ and $\mathrm{BH} 4$ ) were processed and analyzed for hydraulic/hydro-geological properties such as moisture content, grain size distribution, porosity, 
specific gravity, bulk density and permeability using standard methods.

\section{RESULTS AND DISCUSSION}

\section{Lithological Units}

Presented in Figures $5(\mathrm{a} \& \mathrm{~b})$ are the borehole lithologic logs correlated along two preferred orientations (WNW-ESE and SSW-NNE directions) from nine shallow $(<10 \mathrm{~m})$ and two deep holes $(\geq 10 \mathrm{~m})$ that are spatially distributed within the study area. These logs showed that the study area is underlain predominantly by sandy deposits within the upper $17.5 \mathrm{~m}$. The subsoil stratification can be classified as intercalation of sand and clayey sand. The upper sand is finedgrained with thicknesses ranging from $4.5 \mathrm{~m}$ to 6 $\mathrm{m}$ and above $10 \mathrm{~m}$ at the northern and southern end of the study area respectively. The clayey sand is predominantly sand with tiny balls of low plastic clay that occur to a maximum depth of $10 \mathrm{~m}$. The basal sand is fine to medium grained sand observed at depth ranging between $10 \mathrm{~m}$ and 17.5 $\mathrm{m}$. This column of thick sandy materials matched the description of CPS by Kogbe (1989) as being occasionally cross-bedded and predominantly of estuarine, deltaic and continental origin. It also fits the description of the thick bodies of yellowish cross-bedded sands given by Longe, 2011 and Adeigbe etal., 2014.

\section{Hydraulic and Geotechnical Characteristics of Soil within the Study Area}

Table 1 presents the summary of results and statistics obtained from analyses performed on soil profile bulk samples. The bulk and dry density values of soil samples ranged from $1.50 \mathrm{~g} / \mathrm{cm}^{3}$ to $2.01 \mathrm{~g} / \mathrm{cm}^{3}$ and $1.05 \mathrm{~g} / \mathrm{cm}^{3}$ to $1.72 \mathrm{~g} / \mathrm{cm}^{3}$. These density values increased with depth in most of the boreholes. The Natural Moisture Content (NMC) ranged from $5.0 \%$ at $0 \mathrm{~m}$ and $1 \mathrm{~m}$ depth in $\mathrm{BH} 1$ to a peak value of $66.05 \%$ at depth of $1 \mathrm{~m}$ in $\mathrm{BH} 4$. Most samples from all the boreholes in the study area had low NMC less than $20 \%$ with a mean of $17.57 \pm 3.58 \%$.

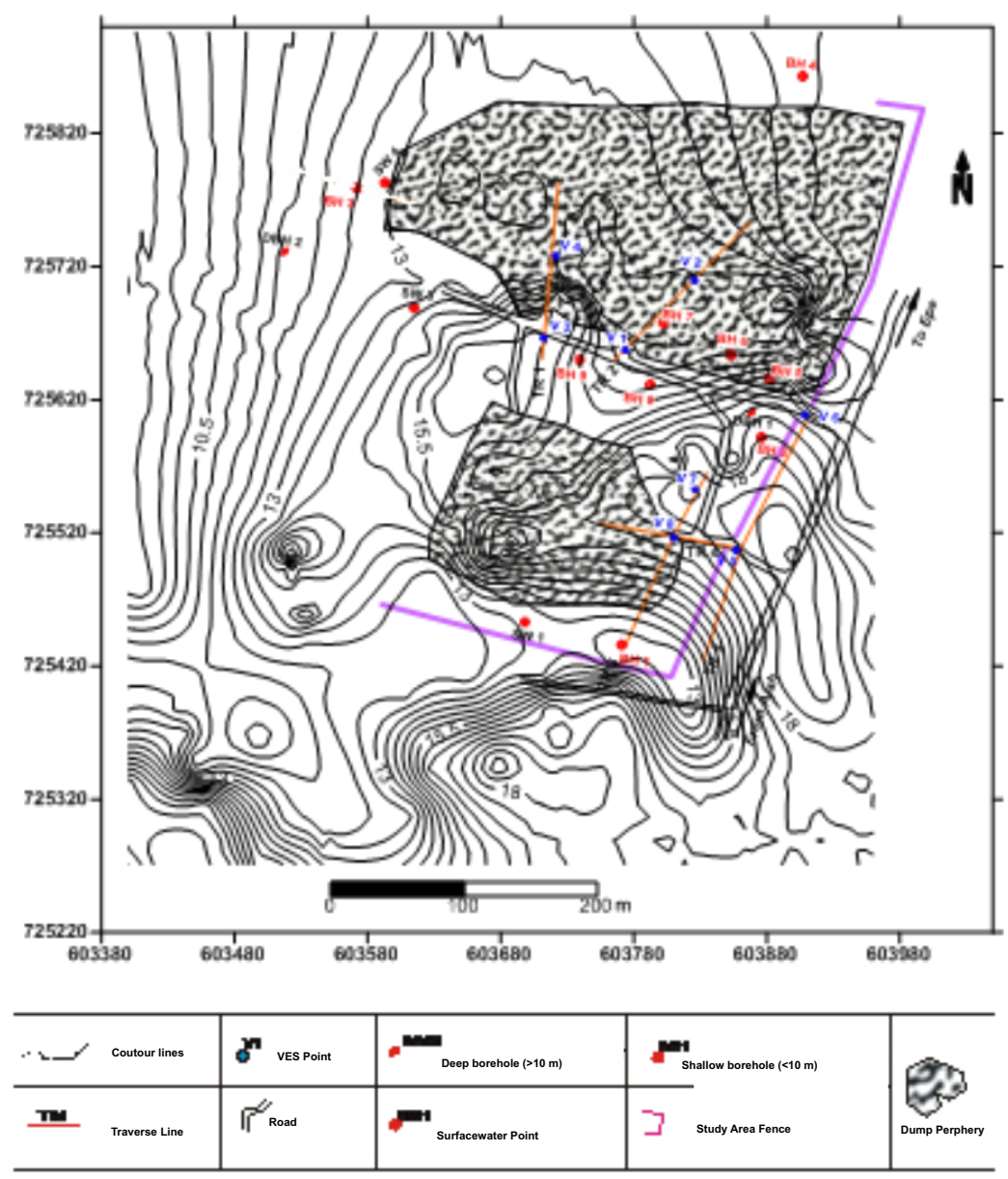

Fig. 3: Topographical Map Showing Details for both Geophysical and Geotechnical Survey on the Active Portion of the Dumpsite (Modification from Konsadem Associate Limited, 2012) 


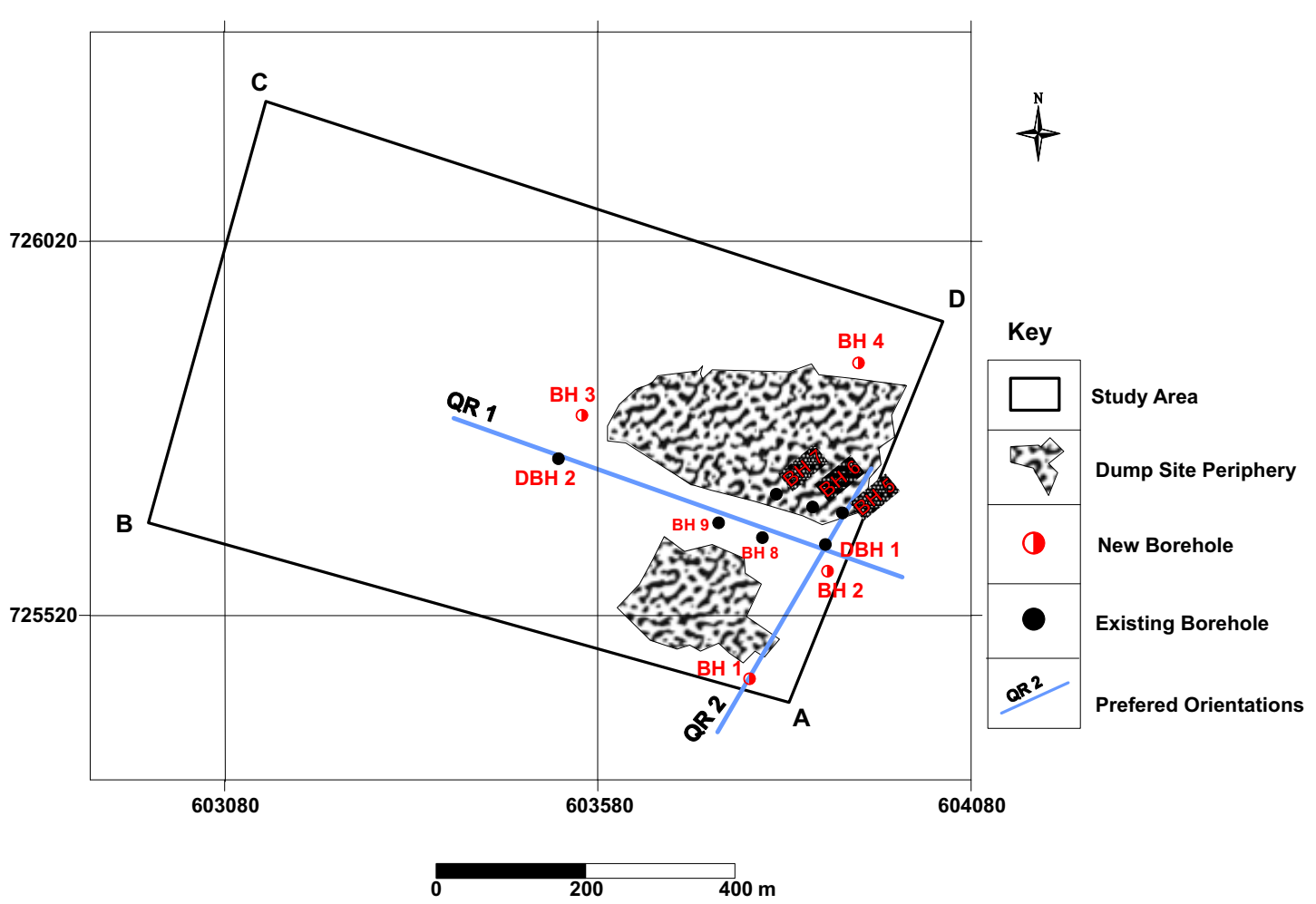

Fig. 4: Map of the Study Area Showing Location of New and Existing Boreholesand Preferred Orientations for Logs

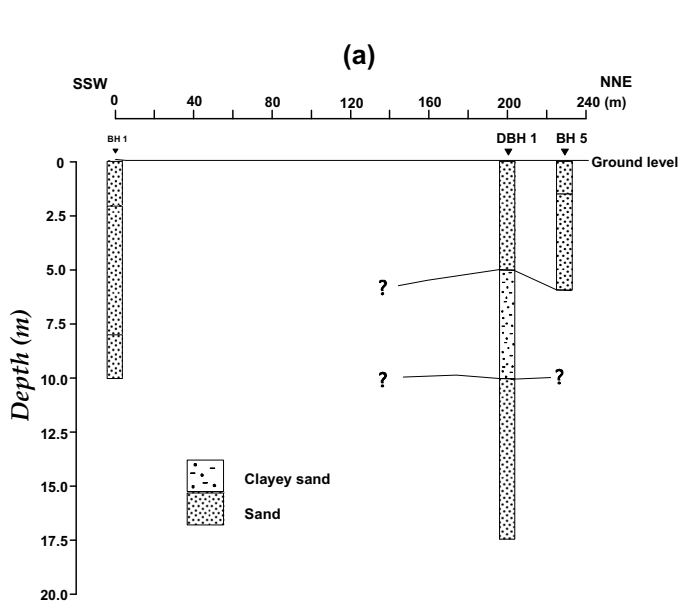
Correlation

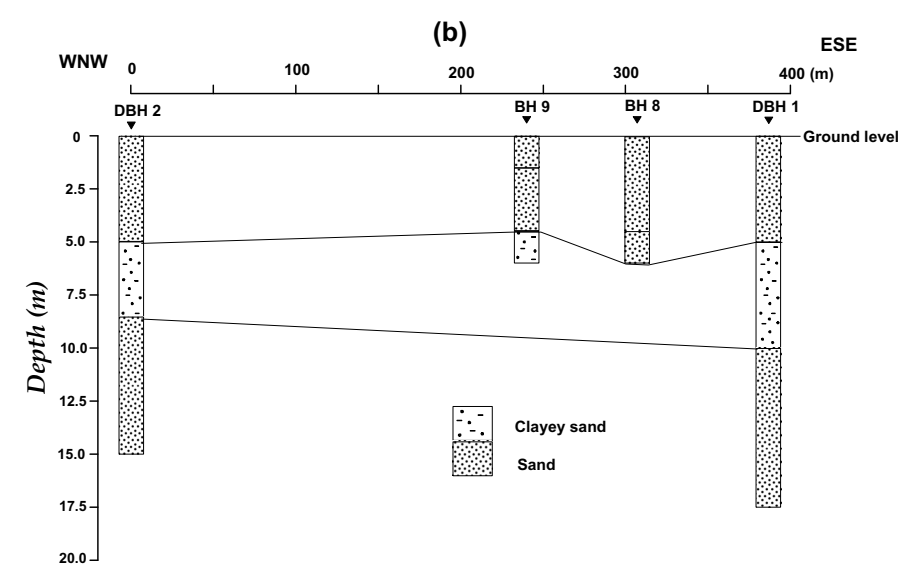

Fig. 5: Correlation of Borehole Lithologic Logs along (a) WNW-ESE Direction and (b) SSW-NNE Direction

Table 1: Descriptive Statistics of Soil Geotechnical/Hydraulic Parameters

\begin{tabular}{lllll}
\hline Parameter & $\mathrm{N}$ & Min & Max & Mean \\
\hline Bulk Density & 18 & 1.50 & 2.01 & $1.89 \pm 0.162$ \\
Dry Density & 18 & 1.05 & 1.72 & $1.52 \pm 0.229$ \\
Natural Moisture & & & & \\
Content & 18 & 5.00 & 66.05 & $17.57 \pm 15.18$ \\
Porosity & 18 & 28.74 & 60.21 & $37.84 \pm 8.42$ \\
Specific Gravity & 18 & 2.29 & 2.68 & $2.54 \pm 0.11$ \\
Void Ratio & 18 & 0.40 & 1.51 & $0.60 \pm 0.28$ \\
Permeability & 18 & $1.0 \times 10^{-4}$ & $5.0 \times 10^{-4}$ & $3.0 \times 10^{-4} \pm 1.1 \times 10^{-4}$ \\
$\mathrm{C} \mu$ & 18 & 1.294 & 13 & $3.042 \pm 2.755$ \\
$\mathrm{Cc}$ & 18 & 0.632 & 1.984 & $1.086 \pm 0.302$ \\
\hline $\mathrm{C} \mu-$ Coefficient of Uniformity & Cc - Coefficient of Curvature
\end{tabular}


However, samples collected from $\mathrm{BH} 4$ recorded higher NMC values of $44.5 \%$ and $66.05 \%$ at 0 and $1 \mathrm{~m}$ depths respectively suggesting that the soils have a higher water retention capacity. The high NMC for samples collected from BH4 also substantiates low density characteristics recorded from same borehole. In line with the trend recorded in density values, natural moisture content of soil samples analyzed were observed to increase with depth in all boreholes sampled. For instance, $5 \%$ moisture content value was observed for soil sample collected at the surface $(0 \mathrm{~m})$ and 1 $\mathrm{m}$ depth in $\mathrm{BH} 1$, with the value increasing up to $19 \%$ in soil sample collected at $8 \mathrm{~m}$ depth in the same borehole. Porosity ranged from $28.7 \%$ to 47.2\% (mean: $37.84 \pm 8.42 \%$ ) in boreholes $\mathrm{BH} 1$, $\mathrm{BH} 2$ and $\mathrm{BH} 3$. For $\mathrm{BH} 4$, porosity was higher ranging between $50.81 \%$ and $60.21 \%$.

Based on the Unified Soil Classification System (USCS), all samples except those at $6 \mathrm{~m}$ depth in $\mathrm{BH} 3$ and two others collected at the surface $(0 \mathrm{~m})$ and $1 \mathrm{~m}$ depth from $\mathrm{BH} 4$, contained $<5 \%$ of fines (silt/clay) and more than $90 \%$ sand fractions. Generally, most analyzed samples are fine to medium grain sand, with decreasing values of percentage-fines as depth of sampling increased. With $C \mu$ values of $<6$ for most soil samples, the grain size statistics (D10, D30, D60 and C $\mu$ and $\mathrm{Cc}$ ) confirmed samples as being poorly graded sand (SP). Soil permeability ranged from1.0 $10^{-4}$ $\mathrm{cm} / \mathrm{s}$ to $5.0 \times 10^{-4} \mathrm{~cm} / \mathrm{s}$. With no definite profile pattern, all permeability values fall within the range classified as moderately permeable.

\section{VES Interpretation Result and Type Curve}

Displayed in Table 2 are the VES interpretation results (layer resistivities and thicknesses) from the VES carried out within the study area. Six (6) VES type curves, namely $\mathrm{H}, \mathrm{HK}, \mathrm{QH}, \mathrm{KQ}, \mathrm{AK}$ and HKHK (Figs. 9 and 12) ranging between three to six geoelectric layers were identified. It was observed that all the VES located within and close to $(<20 \mathrm{~m})$ the waste dump periphery were characterised by $\mathrm{H}, \mathrm{HK}, \mathrm{QH}$ and HKHK curve types (Fig. 12) with decreasing layer resistivities (7 - $510 \Omega \mathrm{m}$ ) within the upper two to three geoelectric layers while those that are far away from the waste dump (VES5-7) were characterised by HK, KQ and AK types (Fig. 9) with increasing layer resistivities $(396-5618 \Omega \mathrm{m})$ within the upper two to three geoelectric layers except the HK type.

\section{Geoelectric Characteristic of the Unimpacted Soil}

The subsoil geoelectric characteristic beneath the unimpacted zone was determined along a control traverse (TR5). Figure 6 (c) shows the 2-D resistivity image along Traverse TR 5 . The image delineates two geologic layers. These layers are sand with resistivity values ranging between 203 $\Omega \mathrm{m}$ and $2056 \Omega \mathrm{m}$ in brown/yellow/green colour and clay with resistivity values less than $100 \Omega \mathrm{m}$ in blue colour. The resistivity values of the sand layer generally decreased with depth. The image reveals occasional deposition of pocket of clay at depth greater than $10 \mathrm{~m}$ while the upper $10 \mathrm{~m}$ is completely characterized by sandy deposits with resistivity values generally $>447 \Omega \mathrm{m}$.

\section{Impact Assessment from Geoelectric Characteristics}

The unimpacted subsoil underlying the study area is known to be composed of predominantly sand within the top $10 \mathrm{~m}$ with relatively high resistivity values ranging from 203 - $9889 \Omega \mathrm{m}$ (generally $>$ $447 \Omega \mathrm{m}$ ) and AK and KQ VES type curves. The sand is underlain by low resistivity clay. Any significant reduction in the layer resistivity value of the high resistivity near-surface sandy subsoil could be attributed to the influence of leachate.

Figure 7 (c) shows the 2-D resistivity image along Traverse TR 4. The traverse has one of its flanks (stations $0-7$ ) within the unimpacted land while the remaining part (stations $7-20$ ) is located within the waste dump. The image revealed that within the unimpacted land, one geologic layer, a sand deposit, underlain this traverse within the upper $7.5 \mathrm{~m}$. This layer, in brown/yellow/green colour, has resistivity values that ranged from 212 to $2165 \Omega \mathrm{m}$ which generally decrease towards the waste dump site. Relatively high resistivity values $(100-149 \Omega \mathrm{m})$ at a depth range of 0 to $2.8 \mathrm{~m}$ within the waste dump site (stations 6 to 11) also characterized the traverse. The relatively high resistivity layer within the waste dump might be due to the recent sand deposit used to reclaim the area for ease of accessibility of trucks dumping waste at this location. The reclaimed area (with sands deposit) was clearly visible along path way at this location. The interpretation model of VES 8 
located within this area significantly correlated with the 2-D resistivity structure (see Table 2 ). The interpretation model of VES 5 located within the unimpacted area is characterized by relatively high resistivity values $(549-1917 \Omega \mathrm{m})$ within the upper $9.3 \mathrm{~m}$. However, relatively low resistivities $(3-118 \Omega \mathrm{m})$ within and around the waste dump site (stations $6-18$ ) were observed on the 2-D image. This zone in blue colour has resistivity values lesser than the threshold resistivity values of the unimpacted upper sand which revealed that the subsoils within this area had been polluted with contaminant plume emanating from the waste dump site. Pollution migration is observed to be generally vertical when compared with the field observed waste dump periphery with little or no lateral migration.

The 2-D resistivity structure (Fig. 8c) along Traverse TR 3 which has its two flanks (stations 0 - 10 and $23-28$ ) outside the waste dump site periphery delineated two geologic layers namely; the sand and clay layers. The upper layer, in brown/yellow/green colour with thicknesses ranging from 4.0 to $>7.5 \mathrm{~m}$, is characterized by resistivity values that varied between 331 and 9889 $\Omega \mathrm{m}$. These values are typical of the unimpacted near-surface sandy material. These resistivity values corroborated those obtained from VES 7 $(463-5618 \Omega \mathrm{m})$ with typical AK type curve (Fig. 9) located within the unimpacted area. The clay layer (blue colour) is observed between stations (4 - 8) at depth beyond $5 \mathrm{~m}$. Significantly low resistivities (5 $-154 \Omega \mathrm{m})$ observed between stations $(10-23)$ relative to the flanking unimpacted areas and the controlled threshold resistivity values could be attributed to the influence of leachate from the waste dump site. This zone correlated perfectly with the field observed waste dump boundary which suggests vertical migration of pollution plume to depth beyond $7.5 \mathrm{~m}$. 
Table 2: Summary of the VES Interpretation Results

\begin{tabular}{|c|c|c|c|c|c|c|c|}
\hline $\begin{array}{l}\text { Traverse } \\
\text { No. }\end{array}$ & $\begin{array}{l}\text { VES } \\
\text { No. }\end{array}$ & $\begin{array}{l}\text { Remark on } \\
\text { Proximity } \\
\text { to Dump }\end{array}$ & $\begin{array}{l}\text { No. of } \\
\text { Layers }\end{array}$ & $\begin{array}{l}\text { Resistivity } \\
(\Omega \mathrm{m})\end{array}$ & $\begin{array}{l}\text { Thickne } \\
\text { ss (m) }\end{array}$ & $\begin{array}{l}\text { Depth } \\
\text { (m) }\end{array}$ & $\begin{array}{l}\text { Type } \\
\text { Curve }\end{array}$ \\
\hline \multirow{9}{*}{ 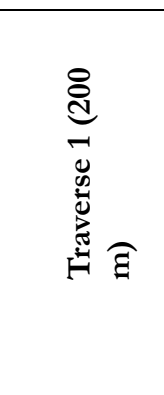 } & \multirow{3}{*}{3} & ** & 1 & 272 & 2.9 & 2.9 & \multirow{3}{*}{$\mathrm{H}$} \\
\hline & & $18 \mathrm{~m}$ away & 2 & 100 & 15.2 & 18.2 & \\
\hline & & & 3 & 356 & - & & \\
\hline & \multirow{4}{*}{4} & $*$ & 1 & 139 & 0.8 & 0.8 & \multirow{3}{*}{$\mathrm{H}$} \\
\hline & & within & 2 & 12 & 11.5 & 12.3 & \\
\hline & & dump & 3 & 31 & - & - & \\
\hline & & & 1 & 501 & 0.7 & 0.7 & \multirow{4}{*}{ QH } \\
\hline & \multirow{3}{*}{1} & $* *$ & 2 & 158 & 9.3 & 10.0 & \\
\hline & & $15 \mathrm{~m}$ away & 3 & 26 & 13.7 & 23.7 & \\
\hline \multirow{8}{*}{ 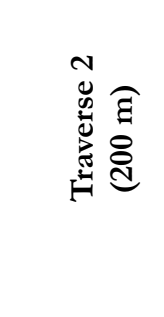 } & & \multirow{6}{*}{$\begin{array}{l}* \\
\text { within } \\
\text { dump }\end{array}$} & 4 & 1177 & - & - & \\
\hline & \multirow{5}{*}{2} & & 1 & 65 & 0.7 & 0.7 & \multirow{5}{*}{$\mathrm{HK}$} \\
\hline & & & 2 & 7 & 4.3 & 5.0 & \\
\hline & & & 3 & 35 & 26.8 & 31.7 & \\
\hline & & & 4 & 1635 & - & - & \\
\hline & & & 1 & 463 & 0.9 & 0.9 & \\
\hline & \multirow{3}{*}{7} & $* * *$ & 2 & 1109 & 4.6 & 5.5 & \multirow{3}{*}{$\mathrm{AK}$} \\
\hline & & $35 \mathrm{~m}$ away & 3 & 5618 & 6.7 & 12.2 & \\
\hline \multirow{10}{*}{ 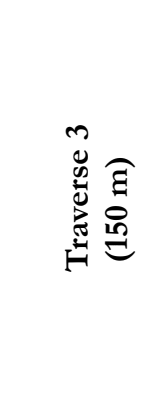 } & & & 4 & 49 & - & - & \\
\hline & \multirow{7}{*}{8} & \multirow{6}{*}{$\begin{array}{l}* \\
\text { within } \\
\text { dump }\end{array}$} & 1 & 425 & 0.7 & 0.7 & \multirow{6}{*}{ HKHK } \\
\hline & & & 2 & 216 & 0.7 & 1.4 & \\
\hline & & & 3 & 727 & 1.4 & 2.8 & \\
\hline & & & 4 & 177 & 5.9 & 8.8 & \\
\hline & & & 5 & 359 & 11.7 & 20.4 & \\
\hline & & & 6 & 38 & - & - & \\
\hline & & & 1 & 1689 & 1.1 & 1.1 & \multirow{4}{*}{$\mathrm{HK}$} \\
\hline & \multirow{3}{*}{5} & $* * *$ & 2 & 549 & 2.2 & 3.2 & \\
\hline & & \multirow[t]{2}{*}{35 away } & 3 & 1917 & 6.1 & 9.3 & \\
\hline \multirow{7}{*}{ 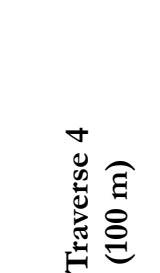 } & & & 4 & 95 & - & - & \\
\hline & & & 1 & 425 & 0.7 & 0.7 & \multirow{6}{*}{ HKHK } \\
\hline & & * & 2 & 216 & 0.7 & 1.4 & \\
\hline & & * & 3 & 727 & 1.4 & 2.8 & \\
\hline & 8 & within & 4 & 177 & 5.9 & 8.8 & \\
\hline & & dump & 5 & 359 & 11.7 & 20.4 & \\
\hline & & & 6 & 38 & - & - & \\
\hline \multirow{8}{*}{ 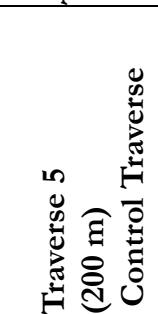 } & \multirow{4}{*}{5} & & 1 & 1683 & 1.2 & 1.2 & \\
\hline & & $* * *$ & 2 & 438 & 1.7 & 2.8 & \\
\hline & & $35 \mathrm{~m}$ away & 3 & 2084 & 6.1 & 8.9 & HK \\
\hline & & & 4 & 94 & - & - & \\
\hline & & & 1 & 396 & 0.5 & 0.5 & \\
\hline & & $* * *$ & 2 & 4563 & 1.2 & 1.8 & \\
\hline & 6 & $22 \mathrm{~m}$ away & 3 & 518 & 17.7 & 19.5 & KQ \\
\hline & & & 4 & 16 & - & - & \\
\hline
\end{tabular}

* $\quad$ VES Locations within the Waste Dump

** VES Locations outside the Waste Dump - not used for geoelectric characterization of the unimpacted soil

*** VES Locations outside the Waste Dump - used for geoelectric characterization of the unimpacted soil 

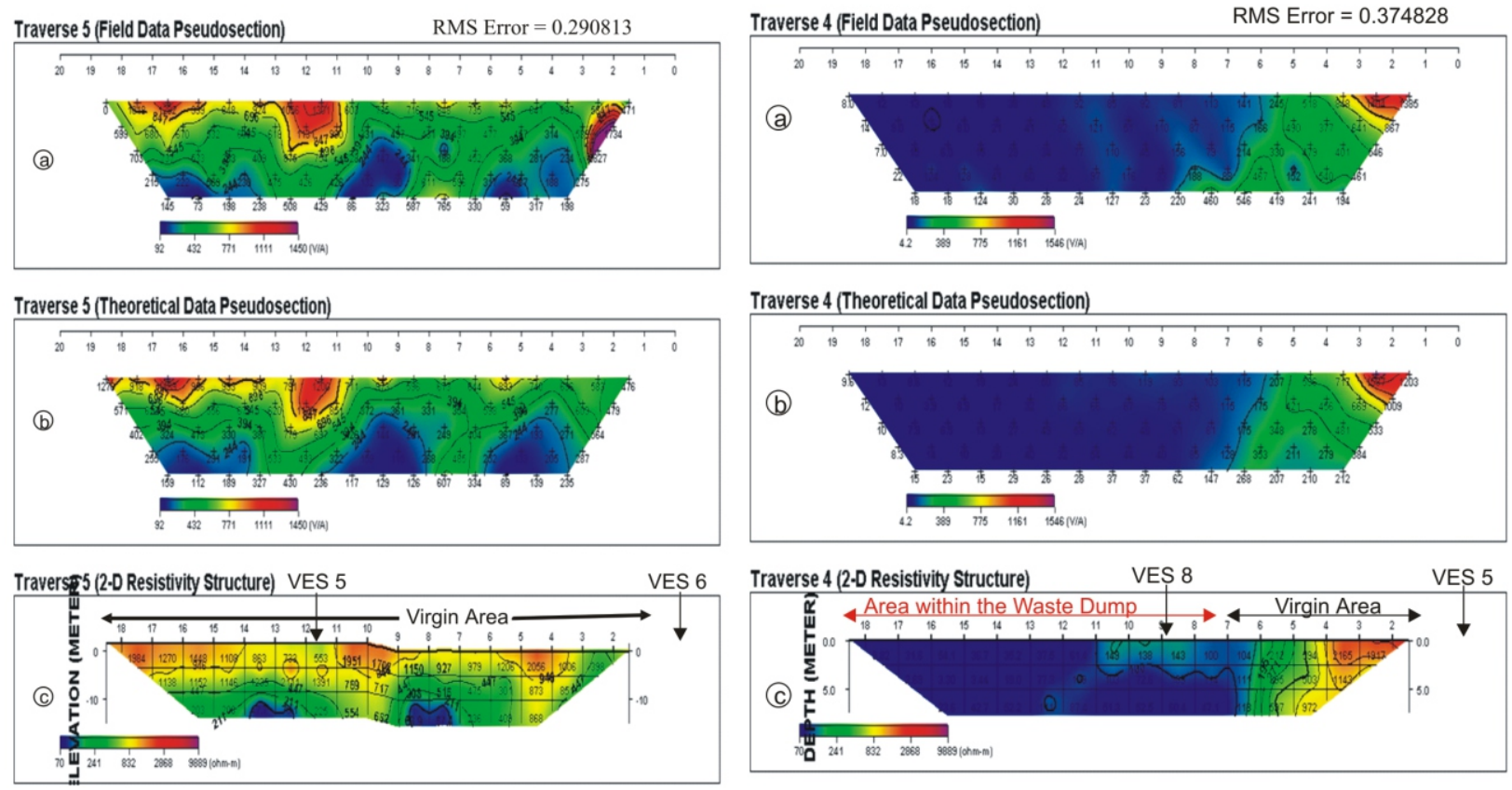

Fig 6 (a): Field Pseudosection (b) Theoretical Pseudosection and (c) 2-D Resistivity Structure along Traverse TR 5

Fig 7 (a): Field Pseudosection (b) Theoretical Pseudosection and (c) 2-D Resistivity Structure along Traverse TR 4
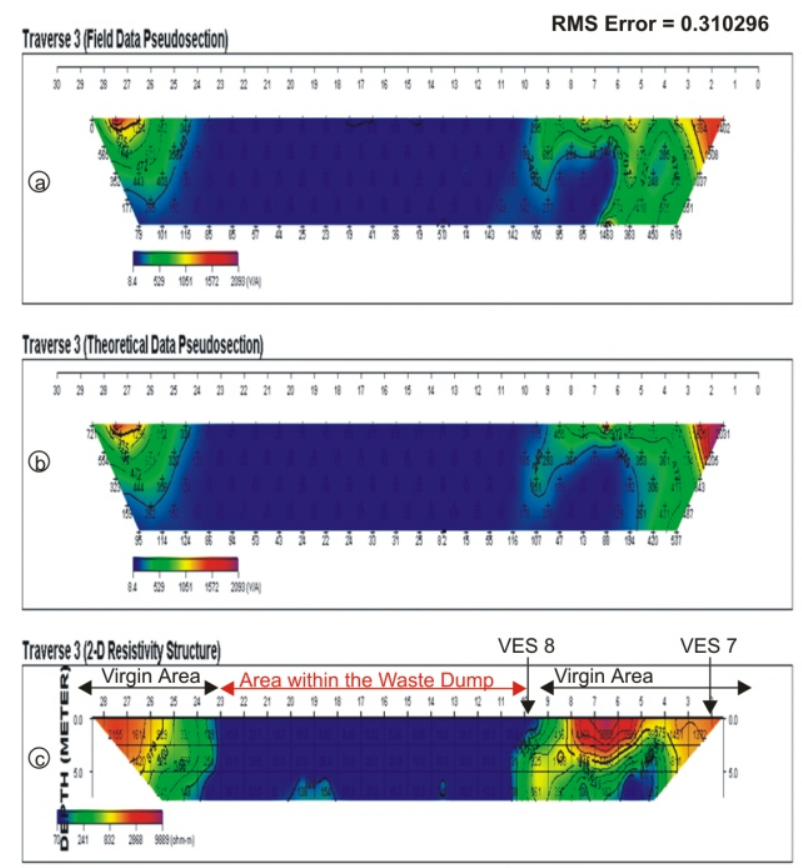

Fig 8 (a): Field Pseudosection (b) Theoretical Pseudosection and (c) 2-D Resistivity Structure along Traverse TR 3

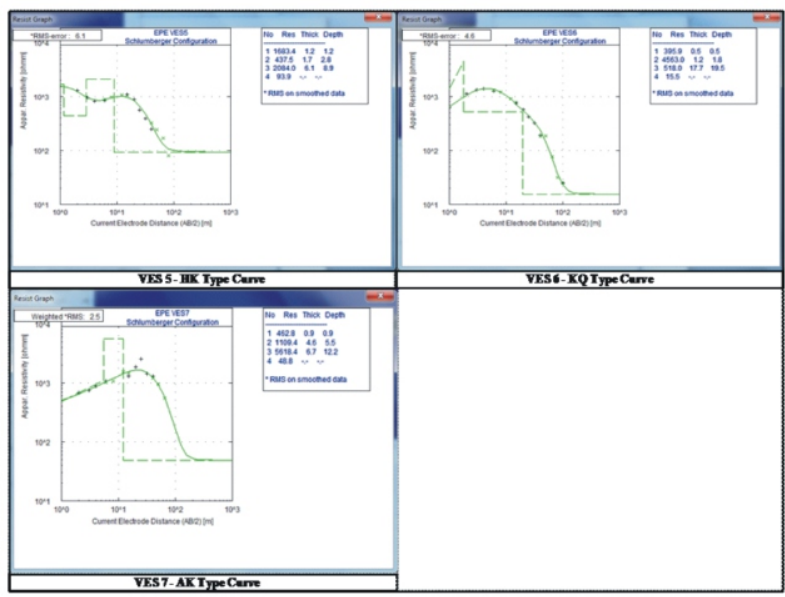

Fig. 9: VES Type Curves within the Unimpacted Section of the Study Area 
Figure 10 (c) shows the 2-D resistivity image along Traverse TR 1. Stations $0-6$, of this traverse fall outside the waste dump boundary while the remaining part, between stations $(6-19)$, are within the waste dump site. Along this traverse, the 2-D image revealed relatively high and extremely low resistivity zones. The relatively high resistivity zones $(160-6281 \Omega \mathrm{m})$, typical of unimpacted sand deposit significantly fall outside the waste dump and some area within the waste dump. The extremely low resistivity zone (blue colour) between stations $(4-17)$ with resistivities of between 4 and $50 \Omega \mathrm{m}$ completely falls within the waste dump site and some portions outside the waste boundary. The low resistivity values show significant reduction in the known resistivity values of the near surface sand typical of the study area. The VES interpretation model of VES 3 and 4 located within the low resistivity zone is characterized by $\mathrm{H}$ type curve (Fig. 12) and also low resistivity values $(12-272 \Omega \mathrm{m})$ within the upper two layers. The observed low resistivities can be attributed to the influence of leachate emanating from the waste dump due to biodegradation of waste materials within the waste dump site. Migration of pollution plume is observed to be significantly vertical while lateral migration favours the south direction.

Along Traverse TR 2, Figure 11 (c) shows the 2-D resistivity image. The traverse falls entirely within the waste dump site. The image shows that the entire traverse is underlain be relatively low resistivities in the range between 5 and $102 \Omega \mathrm{m}$. These low resistivities are typical of area impacted by pollution plume. The soil/subsoil beneath this traverse is observed to be polluted up to depth $>$ $15 \mathrm{~m}$ with both vertical and lateral pollution plume migration. Typical VES type curve within this area is the $\mathrm{H}$ type (Fig. 11).

\section{CONCLUSION}

From the results of the geophysical investigation, borehole lithological logs and geotechnical analysis, it is observed that the study area is underlain by a thick column of poorly sorted unconsolidated sandy formation within the upper $10 \mathrm{~m}$. This sandy layer is characterized by low bulk and dry density; moderate porosity; low moisture content; and substantial hydraulic conductivity. Relatively low resistivity values $(3-118 \Omega \mathrm{m})$ observed within and around the waste dump periphery are typical of contaminant leachate impacted zones relative to high resistivity values $(203-9889 \Omega \mathrm{m})$ observed within the unimpacted area. It can therefore be concluded that the soil/subsoil and water within and around the Epe wetland waste dump site periphery had been polluted from the surface up to depths beyond 15 $m$ with leachates emanating from the dump site. 


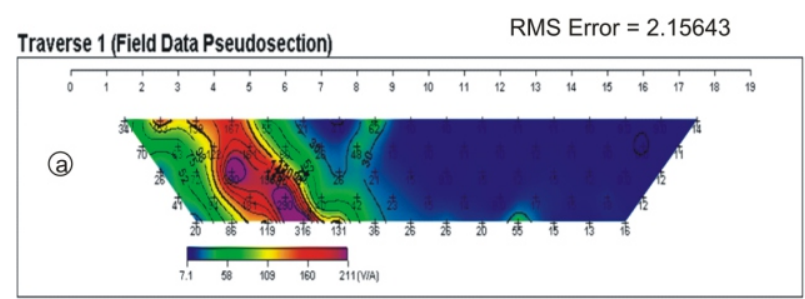

Traverse 1 (Theoretical Data Pseudosection)

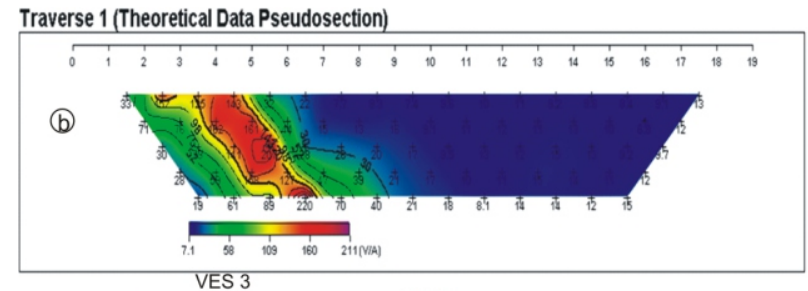

Traverse 1 (2-D Resistivity Structure) VES 4

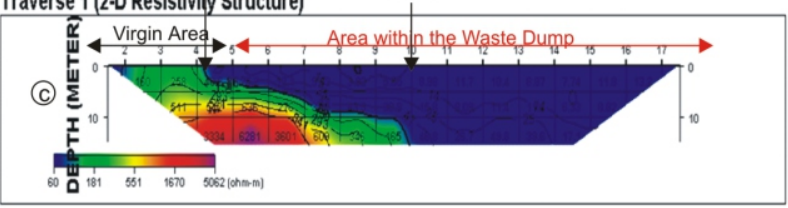

Fig 10 (a): Field Pseudosection (b) Theoretical Pseudosection and (c) 2-D Resistivity Structure along Traverse TR 1
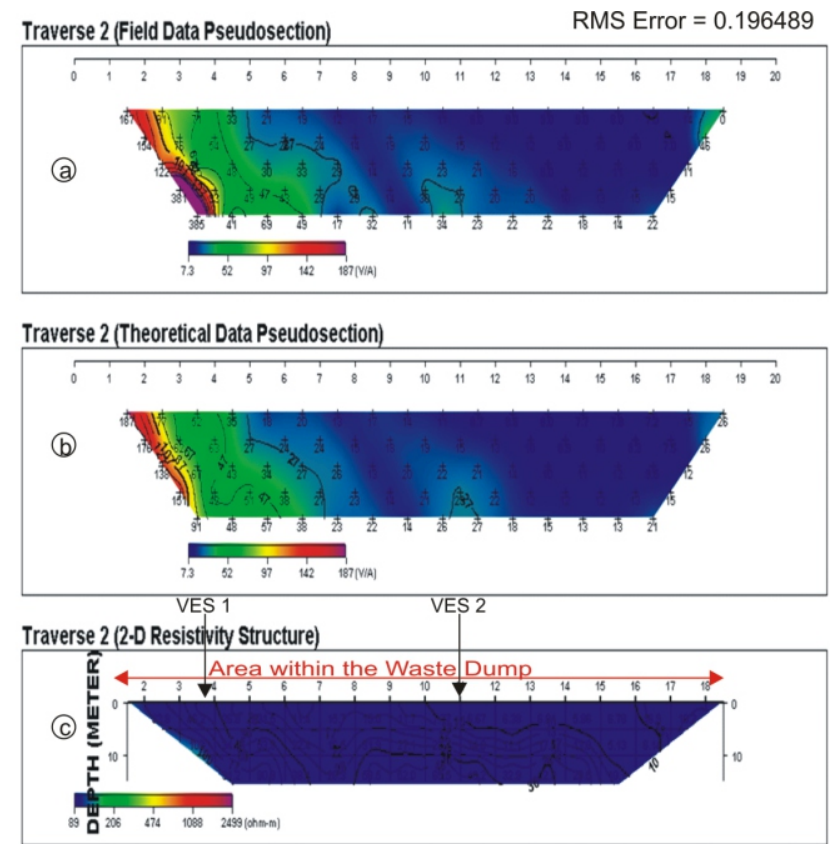

Fig 11 (a): Field Pseudosection (b) Theoretical Pseudosection and (c) 2-D Resistivity Structure along Traverse TR 2

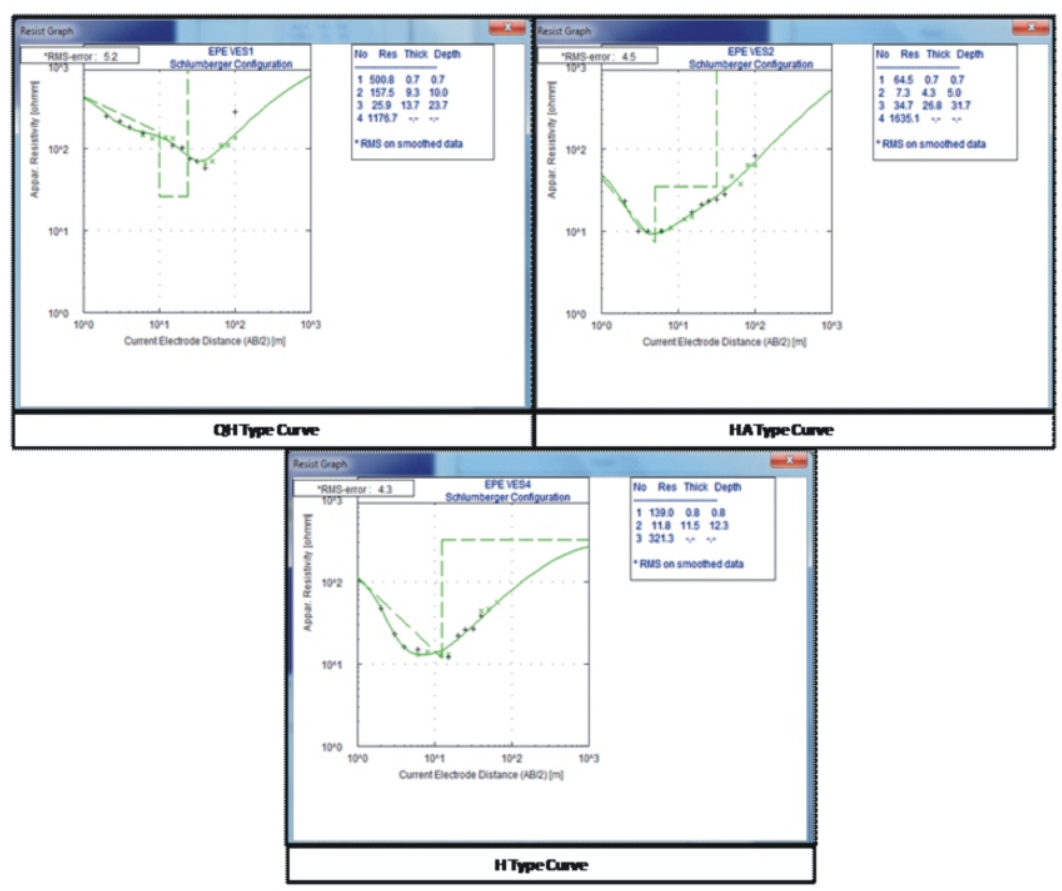

Fig. 12: Typical VES Type Curves within the Waste Dump Area

\section{REFERENCES}

Adeigbe, O. C.; Adebowale, M.; Ola-Buraimo, A. O.; Bankole, S. A. and Ayinla, H. A. (2014). Calcareous Nannofossils and Foraminifera Studies: An Integrated Approach to the Depositional Environmental Study and Biostratigraphy of Deb-1 well offshore Eastern Dahomey
Basin, Southwestern Nigeria. British Journal of Applied Science \& Technology 4(2), 319-337

Akinmosin, A.; Osinowo, O. and Adio, N. (2010). Use of Stable Carbon Isotope in Characterization of Tar Sand Deposit in Southwestern Nigeria. Journal of Applied Sciences in Environmental Sanitation, 5 (4), 
317-328

Derakhshandeh, M. and Tokatam, T. B.

(2014).Management of Landfill Locating

of Urban Waste. European Online Journal

of Natural and Social Sciences. Special Issue

on Environmental, Agricultural and Energy

Science 3 (3), 32-39.

Enikanselu, P. A. (2008). Detection and Monitoring of Dumpsite-Induced Groundwater Contamination using Electrical Resistivity Method.The Pacific Journal of Science and Technology 9 (1), 254 262

Hughes, G. M. (1972). Hydrogeologic considerations in the siting and design of landfills.Illinois state geological survey. Digitized by the internet arcieve in 2012 with funding from University of Illinois. Urbanachampaign.http://archive.org/de tails/hydrogeologiccon51 hugh

Ibitola, M. P.; Ehinola, O. A., and Akinnigbagbe, A. E. (2011).Electrical Resistivity Method in Delineating Vadose and Saturated Zone in some Selected Dumpsites in Ibadan Part of South-Western, Nigeria. International Journal of Geomatics and Geosciences 2 (1), 164-178.

Jones, H. A. and Hockey, R. D. (1964).The Geology of part of southwestern Nigeria. Geological Survey of Nigeria (GSN) Bulletin, vol31, 101.

Kogbe, C. A. (1989). The Cretaceous and Paleogene Sediments of Southern Nigeria: In Kogbe C. A. (Ed.), Geology of Nigeria Vo. II. Elizabethan Publ., Lagos, Nigeria. 273286pp

Lee, G. Fred and Associate, El macero, C.A (1999).Detecting Failure of Subtitle D Landfill Linear Systems. Published by Centre for Health, Environment and Justice (CHEJ) 2015.Landfill Failures the Buried Truth. Fact Pack- PUB 009. Also available at: http: / / www.gfredlee.com/detecting failure.pdf

Longe, E. O. and Balogun, M. R. (2010).Groundwater quality assessment near a municipal landfill, Lagos. Nigeria Research Journal of Applied Sciences, Engineering and Technology 2(1), 39-44.

Longe, E. O. (2011). Groundwater Resources Potential in the Coastal Plain Sands
Aquifers, Lagos, Nigeria.Research Journal of Environmental and Earth Sciences,3(1), 1-7

Nigeria Geological Survey Agency (NGSA) 2006.The Geological Map of Lagos State. Published by the Authority of the Federal Republic of Nigeria

Nitin, K. and Mohrana, C. (2013).Impact of solid waste disposal on ground water quality near Gazipur, Delhi, India. Journal of Applied and Natural Science 5 (2), 306-312

Obiora, D. N. and Onwuka, O. S. (2005). Groundwater Exploration in Ikorodu, Lagos-Nigeria: A Surface Geophysical Survey Contribution. The Pacific Journal of Science and Technology, 6 (1), 86:93

O'Leary, P. R., (1983). Solid Waste Landfills. Madison, WI: University of WisconsinExtension.

Omatsola, M. E. and Adegoke, O. S. (1981).Tectonic evolution and Cretaceous stratigraphy of the Dahomey Basin. Nigerian Journal of Mining Geology, 18 (1), $130-137$.

Onyegoke, E. S. (1986). The hydrology of Lagos Metropolis. Nigeria Water and Sanitation Association (NWASA) Proceeding of the First Annual Symposium and Exbibition on Ground Water Resources in Nigeria, $23^{r d}-25^{\text {th }}$ July, 1986, pp. 68-80.Opara, A. I. (2011). Estimation of the Depth to Magnetic Basement in Part of the Dahomey Basin, South-western Nigeria. Australian Journal of Basic and Applied Sciences, 5 (9), 335-343.

Oyediran, I. A. and Adeyemi, G. O. (2011).Geotechnical investigations of a site in Ajibode, Southwestern Nigeria for landfill. Ozean Journal of Applied Sciences, 4(3) 265-279

Ross, H. P.; Mackelprang, C. E. and Wright, P. M. (1990). Dipole-Dipole electric resistivity surveys at waste disposal study sites in Northern Utah. In Ward, S. H. (Ed) Geotechnical and Environmental Geophysics. Society of Exploration Geophysics Vol. I-III: 145-152.

Splajt, T., Ferrier, G. and Frostick, L.E. (2003).Application of ground penetrating radar in mapping and monitoring landfill sites. Env. Geol., 44: 963-967.

United States Environmental Protection Agency (USEPA), 2012. Five-year review report 
for Yeoman Creek landfill superfund site Lake County, Illinois. USEPA Region 5 Chicago, Illinois. Pp37.

United States Environmental Protection Agency (USEPA), 2014. Waste - Non-hazardous Waste - Municipal Solid Waste. Last updated on 10 January 2014.Available online and accessed on the $20^{\text {th }}$ of July, 2015.http://www3.epa.gov/epawaste/n onhaz/municipal/landfill.htm

Walker, S. and Anderson, R. (2001).Engineering geology overview of municipal solid waste landfills in northern California. Engineering geology practice in northern California. Division of Mine. Buletin 210:38140 